\title{
Broken heart syndrome: a case report
}

\section{Krunoslav Košćak Tomislav Vuger ${ }^{\text {* }}$ Josip Vincelj ${ }^{2}$}

`Varaždin General Hospital, Varaždin, Croatia

${ }^{2}$ Dubrava University Hospital, Zagreb, Croatia

\section{RECEIVED:}

March 30, 2015

ACCEPTED:

April 20, 2015

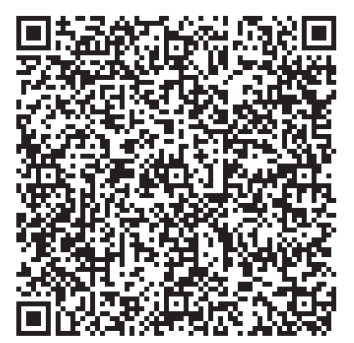

KEYWORDS: acute heart failure, stress, Takotsubo, left ventricular thrombus. CITATION: Cardiol Croat. 2015;10(3-4):84. | DoI: http://dx.doi.org/10.15836/ccar.2015.84

ORCID: Krunoslav Košćak, http://orcid.org/0000-0002-8289-4962 • Tomislav Vuger, http://orcid.org/0000-0001-9739-5114 • Josip Vincelj, http://orcid.org/0000-0003-0064-9128

*ADDRESS FOR CORRESPONDENCE: Tomislav Vuger, Opća bolnica Varaždin, Ivana Meštrovića bb, HR-42000 Varaždin, Croatia. Phone: +385-98-517 390. E-mail: bummbar@live.com

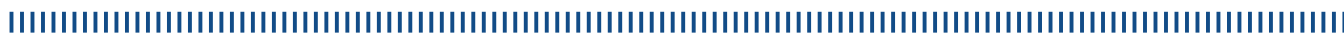

In this poster we are presenting a case of 62-years-old female patient with „broken heart syndrome" also known as Takotsubo cardiomyopathyl, with left ventricular thrombus.

62-years-old female patient with history of hypertension was hospitalized on Cardiology Department with acute hearth failure and chest pain, that started half an hour after very stressful verbal conflict with close relative. 12lead ECG shown inversion of $\mathrm{T}$ wave in lateral leads. Laboratory results of troponin I 0,12ng/ml at arrival rise to $2,45 \mathrm{ng} / \mathrm{ml}$. Echocardiography show typical hypokinesia of apical and mid-left ventricular myocardium with basal hypercontractility. Our conclusion was an acute coronary syndrome. Fourth day there was also forming of a left ventricular thrombus that we monitored. After treating patient with furosemid, ramipril, acetilsalicylic acid and low molecular weight heparin for few days, she was sent to coronary angiography. There was no obstructive coronary artery disease found. Our patient was treated for few more days back in our hospital and fully recovered.

Three month after releasing from hospital on check-up, she had normal 12-lead ECG and echocardiography. From all the data we conclude that she had Takotsubo cardiomyopathy. 